\title{
ANALISIS RESPON MAHASISWA PENDIDIKAN FISIKA TERHADAP COMPUTER BASED TESTING PADA MATA KULIAH MANAJEMEN LAB
}

\author{
${ }^{1)}$ F. K. Ayu Anggraeni, ${ }^{2)}$ Lailatul Nuraini \\ ${ }^{1)}$ Program Studi Pendidikan Fisika FKIP Universitas Jember \\ Email: firdhakusuma@unej.ac.id
}

\begin{abstract}
The using of technology in the field of education especially in college is the using of e-learning. E-learning is a way of teaching and learning activities assisted by information and communication technology. One example of e-learning implementation is test. This type of exam is referred to as an online test or computer based testing (CBT). University of Jember has an e-learning called Media Manajemen Pembelajaran (MMP) and one of the features in it is a quiz feature that can be used by lecturers in giving quizzes, tests, or examinations to students. . The research that has been carried out aims to determine the response of Physics Education students to the implementation of online examinations in Lab Management courses. The question model used in this exam is in the form of multiple choices. After students finish working on the questions, students fill in the questionnaire responses which are then processed and presented in tabular forms, then analyzed descriptively. The results obtained from this study give good results. Students give positive responses to representations about using the online system for exams, the interest of students in taking online exams, easy use of web access, online system test displays and questions, and responses to the methods used in the online system.
\end{abstract}

Keywords: guided inquiry, decision making, physics learning.

\section{PENDAHULUAN}

\begin{tabular}{lr}
\multicolumn{2}{c}{ Pendidikan secara umum } \\
memiliki peranan untuk \\
mengembangkan kemampuan dan
\end{tabular} membentuk karakter dalam rangka mencerdaskan para generasi bangsa. Dalam pendidikan terdapat hal penting yang harus diperhatikan salah satunya adalah proses pembelajaran. Proses pembelajaran terdiri dari beberapa indikator seperti indikator proses dan hasil belajar. Indikator tersebut perlu ditingkatkan kualitasnya sesuai dengan perkembangan zaman sehingga dapat meningkatkan kualitas pendidikan di Indonesia (Sujana, 2019). Seperti halnya di lingkup sekolah, proses pembelajaran di perguruan tinggi melibatkan interaksi antara pendidik (dosen) dan peserta didik (mahasiswa). Seorang pendidik, dalam hal ini dosen memiliki fungsi sebagai seorang yang mampu memfasilitasi dan memotivasi, serta sebagai mediator bagi mahasiswa dalam proses belajar.

Pada proses pembelajaran di perguruan tinggi perlu dilakukan penilaian dan pengukuran dalam bentuk tes hasil belajar bagi para mahasiswa. Pengertian tes adalah suatu pemberian tugas dalam bentuk soal atau perintah yang harus dikerjakan oleh peserta tes (Asrul et.al, 2015). Dengan adanya tes tersebut maka dapat teramati ketuntasan dan keberhasilan belajar mahasiswa dalam satu mata kuliah tertentu. Selain 
mengamati ketuntasan dan keberhasilan, pelaksanaan tes juga untuk mengukur kesiapan dan kesulitan mahasiswa dalam memahami suatu mata kuliah tertentu sehingga dapat ditentukan upaya untuk memperbaiki proses pembelajaran yang berlangsung (Maiziani, 2016).

Perkembangan teknologi yang kian pesat memicu perkembangan di berbagai bidang, salah satunya di bidang pendidikan. Sebagai contoh teknologi digunakan sebagai media dalam membantu proses belajar baik di perguruan tinggi. Bentuk lain dari pemanfaatan teknologi dalam bidang pendidikan di perguruan tinggi adalah penggunaan e-learning (Perkasa et.al, 2015). E-learning merupakan cara pembelajaran di mana penyampaian materinya, pelatihan atau perkuliahan yang dilakukan menggunakan teknologi informasi dan komunikasi (Yuliyanto, 2016). Penggunaan $e$ learning merupakan suatu cara bagi dosen sebagai pendidik agar memudahkan dalam hal menyampaikan materi, pemberian tugas, bahkan pelaksanaan tes/ujian kepada mahasiswa.

Pelaksanaan ujian dengan memanfaatkan e-learning dapat disebut sebagai ujian online atau Computer Based Testing. Pengertian dari Computer Based Testing berdasarkan Olsen dalam Trisnawati (2015) adalah tes dengan memanfaatkan media komputer yang menggunakan konfigurasi baik yang dapat berdiri sendiri maupun menggunakan jaringan atau perangkat teknologi lain yang terkoneksi dengan internet. Ujian online diharapkan dapat menjadi pilihan alternatif bagi sistem pendidikan di perguruan tinggi yang lebih efektif dan efisien (Boeve et al,
2015). Konsep pelaksanaan ujian dengan e-learning adalah memberikan soal, menjawab soal/pertanyaan, hingga memberi nilai terhadap ujian yang dilaksanakan (Perkasa, et.al, 2015).

Universitas Jember adalah salah satu perguruan tinggi yang memiliki fasilitas e-learning dalam pembelajarannya. Hal tersebut merupakan suatu bentuk respon Universitas Jember dalam mengikuti perkembangan teknologi dan menyesuaikan pola pembelajaran dengan media internet. Fasilitas $e$ learning di Universitas Jember disebut dengan Media Manajemen Pembelajaran (MMP) yang terintegrasi juga dengan sistem akademik online Universitas Jember (SISTER). Pada $e$ learning, banyak fasilitas yang dapat digunakan para dosen dalam melakukan kegiatan pembelajaran, seperti mengirim file materi, memberi tugas, melakukan kuis, bahkan kuliah daring (kuliah online).

Pemanfaatan fasilitas $e$ learning tersebut berlaku untuk seluruh Program Studi di lingkungan Universitas Jember, termasuk Program Studi Pendidikan Fisika. Jika berbicara tentang Fisika pasti yang terlintas adalah soal perhitungan matematis. Namun di dalam Program Studi Pendidikan Fisika, tidak semua mata kuliah menggunakan perhitungan, terdapat mata kuliah yang berkaitan dengan ilmu pendidikan yang menjadi bekal sebagai calon guru nanti, salah satunya adalah mata kuliah Manajemen Lab.

Mata kuliah tersebut merupakan mata kuliah wajib guna menunjang dan membekali mahasiswa pada saat terjun menjadi guru saat lulus nanti. Mata kuliah tersebut 
mengkaji tentang cara mengatur dan mengorganisasi lab, bagaimana Standard Operating Procedure (SOP) di dalam laboratorium sekolah dan jenis-jenis SOP, serta kajian-kajian lain yang terkait dengan laboratorium sekolah.

Mengingat bahwa mata kuliah tersebut hanya berisikan teori tanpa perhitungan, maka di sini peneliti ingin memanfaatkan fasilitas e-learning yang dimiliki Universitas Jember untuk memberikan ujian online pada mata kuliah Manajemen Lab. Hal ini dikarenakan untuk persoalan dengan perhitungan fasilitas $e$-learning kurang mewadahi dan masih lebih efektif dengan ujian konvensional (paper based tested) sehingga ujian online lebih mudah untuk mata kuliah yang berisikan teori saja.

Dengan adanya penelitian ini diharapkan mengetahui efekif atau tidaknya ujian online dengan menggunakan e-learning Universitas Jember berdasarkan respon mahasiswa terhadap pelaksanaan ujian online, khususnya mahasiswa yang menempuh mata kuliah Manajemen Lab.

\section{METODE PENELITIAN}

Penelitian ini menggunakan metode penelitian kuantitatif. Metode penelitian kuantitatif adalah metode untuk meneliti populasi atau sampel dengan menggunakan instrumen dalam mengumpulkan data (Mulyadi, 2011). Dalam hal ini instrumennya berupa angket (respon) untuk responden dan hasil angket (respon) akan disajikan dalam bentuk tabel, grafik, atau diagram dan analisis dilakukan secara deskriptif (Mastuti, 2016).

Penelitian tentang efektivitas dan respon penggunaan Computer Based Testing (CBT) dilakukan pada mata kuliah Manajemen Lab semester gasal tahun akademik 2019/2020. Penelitian ini dilakukan dengan menguji coba ujian secara online dengan memanfaatkan fasilitas pada sistem Media Manajemen Pembelajaran (MMP) yang dimiliki Universitas Jember. Langkah awal yang dilakukan adalah membuat soal sebanyak 40. Soal-soal tersebut kemudian diinputkan ke dalam fasilitas quiz yang ada pada MMP.

Setelah ujian dilaksanakan, maka langkah yang dilakukan selanjutnya adalah mengumpulkan data berupa angket respon mahasiswa mengenai pelaksanaan ujian online (computer based testing) dengan responden adalah 32 mahasiswa yang menempuh mata kuliah Manajemen Lab. Prosentase hasil angket respon dalam penelitian ini dihitung dengan menggunakan skala Likert dengan ketentuan pada pernyataan positif adalah sebagai berikut.

1. Skor 4 untuk pilihan sangat setuju /menarik/paham/efektif/banyak.

2. Skor 3 untuk pilihan setuju /menarik/paham/efektif/banyak.

3. Skor 2 untuk tidak setuju/ menarik/paham/efektif/banyak.

4. Skor 1 untuk sangat tidak setuju/ menarik/paham/efektif/banyak.

Sementara untuk pernyataan negatif memenuhi ketentuan sebagai berikut.

1. Skor 4 untuk sangat tidak setuju/ menarik/paham/efektif/banyak.

2. Skor 3 untuk tidak setuju /menarik/paham/efektif/banyak.

3. Skor 2 untuk setuju/ menarik/paham/efektif/banyak.

4. Skor 1 untuk sangat setuju /menarik/paham/efektif/banyak.

Dengan ketentuan skala Likert tersebut akan diperoleh jumlah skor yang akan 
digunakan untuk menghitung Hasil prosentase tersebut kemudian prosentase respon.

$\begin{array}{ll}\text { Prosentase }=\frac{\text { JumlahSkor }}{\text { Skor maksimal }} \times 100 \% & \begin{array}{l}\text { kriteria seperti Tabel } 1 \text { (Rahayu, } \\ \text { 2016). }\end{array}\end{array}$

Tabel 1. Kriteria Presentase

\begin{tabular}{l|l}
\hline Interval Respon Mahasiswa & Kriteria \\
\hline $80 \% \leq \mathrm{Na}<100 \%$ & Sangat positif \\
$60 \% \leq \mathrm{Na}<80 \%$ & Positif \\
$40 \% \leq \mathrm{Na}<60 \%$ & Cukup positif \\
$20 \leq \mathrm{Na}<40 \%$ & Kurang positif \\
$\mathrm{Na}<20 \%$ & Sangat kurang positif \\
\hline
\end{tabular}

\section{HASIL DAN PEMBAHASAN}

Respon mahasiswa diperoleh berdasarkan angket yang diberikan setelah dilaksanakannya ujian secara online atau Computer Based Testing (CBT).
Hasil angket dapat disajikan pada Tabel 2. Dalam tabel hasil angket tersebut, butir pertanyaan pertama hingga keempat menunjukkan tentang respon mahasiswa terhadap penggunaan sistem online untuk ujian.

Tabel 2. Kemampuan siswa mengambil keputusan selama 3 pertemuan pembelajaran.

\begin{tabular}{l|l|l|l}
\hline No. & \multicolumn{1}{|c|}{ Pernyataan } & \multicolumn{1}{|c}{$\begin{array}{c}\text { Rerata } \\
\text { Skor }\end{array}$} & \multicolumn{1}{|c}{$\begin{array}{c}\text { Prosentase } \\
\text { Rerata }\end{array}$} \\
\hline 1 & $\begin{array}{l}\text { Saya menyukai pelaksanaan ujian dengan } \\
\text { sistem ujian online }\end{array}$ & 3,03 & $75,78 \%$ \\
\hline 2 & $\begin{array}{l}\text { Saya menyukai apabila sistem ujian manual } \\
\text { diganti dengan sistem online }\end{array}$ & 2,78 & 69,53 \\
\hline 3 & $\begin{array}{l}\text { Saya tidak menemui kendala saat } \\
\text { melaksanakan ujian online }\end{array}$ & 2,72 & $67,97 \%$ \\
\hline 4 & $\begin{array}{l}\text { Saya kurang memahami prosedur pelaksanaan } \\
\text { ujian online }\end{array}$ & 3,40 & $85,15 \%$ \\
\hline 5 & Menurut saya sistem ujian online itu menarik & 2,97 & $74,21 \%$ \\
\hline 6 & $\begin{array}{l}\text { Saya tidak menemui kendala dalam } \\
\text { mengakses web halaman untuk ujian online }\end{array}$ & 2,56 & $64,06 \%$ \\
\hline 7 & $\begin{array}{l}\text { Saya menyukai ujian online karena dapat } \\
\text { menggunakan sistem pilihan ganda }\end{array}$ & 3,28 & $82,03 \%$ \\
\hline 8 & $\begin{array}{l}\text { Menurut saya penampilan soal dan pilihan } \\
\text { jawaban yang muncul saat ujian kurang jelas }\end{array}$ & 3,13 & $78,13 \%$ \\
\hline 9 & $\begin{array}{l}\text { Menurut saya nilai yang langsung tampil } \\
\text { sesaat setelah ujian dilaksakan menunjukkan } \\
\text { transparansi nilai }\end{array}$ & 3,00 & $75,00 \%$ \\
\hline 10 & $\begin{array}{l}\text { Menurut saya pelaksanaan ujian dengan } \\
\text { metode acak soal itu bagus }\end{array}$ & $2,88 \%$ & $71,88 \%$ \\
\hline
\end{tabular}


Pertanyaan

merepresentasikan

ketertarikan

mengerjakan

pertanyaan keenam merepresentasikan tentang kemudahan penggunaan akses web untuk mahasiswa sebagai peserta ujian. Kemudian pertanyaan ketujuh hingga kesembilan menunjukkan respon terhadap tampilan ujian sistem online dan pertanyaan terakhir merepresentasikan tentang respon terhadap metode yang digunakan dalam sistem online.

Berdasarkan hasil angket respon mahasiswa terhadap pelaksanaan Computer Based Testing (CBT) pada mata kuliah Manajemen Lab dan berdasarkan kriteria presentase $\mathrm{Na}$, secara umum mahasiswa memberikan respon positif yang terhadap pelaksanaan ujian secara online atau Computer Based Testing (CBT). Respon positif diberikan terhadap penggunaan sistem online untuk ujian, ketertarikan mahasiswa dalam mengerjakan ujian online, kemudahan penggunaan akses web, tampilan ujian sistem online, dan metode yang digunakan dalam sistem online.

Respon yang diberikan ini bersifat positif karena penggunaan ujian berbasis online (Computer Based Testing) seperti ini jarang dilakukan dan bersifat baru bagi mahasiswa, utamanya mahasiswa Pendidikan Fisika. Walaupun respon yang diberikan adalah positif namun ada beberapa kendala yang dialami mahasiswa, seperti akses jaringan yang dapat mengganggu kelancaran pelaksanaan ujian. Kelemahan sistem quiz pada MMP ini, jika jaringan terganggu maka ujian akan dimulai dari awal lagi sehingga mahasiswa yang telah mengerjakan beberapa soal jika jaringan terganggu maka ia akan mengulang untuk mengerjakan dari awal.

CBT sendiri sebenarnya memberikan kemudahan bagi mahasiswa dalam melaksanakan tes dengan menggunakan perangkat berupa laptop atau komputer, bahkan handphone. Terdapat fitur-fitur di dalamnya untuk mempermudah penggunaan dan ada pengaturan-pengaturan tertentu untuk meminimalisir kecurangan yang bisa saja dilakukan mahasiswa, seperti pengaturan waktu dan sistem tampilan soal secara acak. CBT ini juga mempermudah kerja dosen untuk menilai dan mengevaluasi hasil belajar terhadap mata kuliah yang diberikan (Maiziani, 2016).

\section{SIMPULAN DAN SARAN}

Berdasarkan hasil penelitian yang telah dilakukan maka diperoleh kesimpulan bahwa pelaksanaan ujian berbasis online atau computer based testing ini direspon baik atau positif oleh mahasiswa Pendidikan Fisika, Universitas Jember. Namun ada kendala yang dialami mahasiswa seperti kestabilam jaringan yang sangat diperlukan dalam mengerjakan soal ujian. Pelaksanaan Computer Based Testing ini sendiri sebenarnya baik dalam meminmalisir kecurangan yang dilakukan mahasiswa dan membantu dosen dalam menilai dan mengevaluasi hasil belajar.

Adapun saran yang diberikan adalah sistem quiz pada MMP sebaiknya diperbaiki agar mahasiswa tidak perlu mengulang soal dari awal apabila terdapat kendala jaringan. Selain itu, fasilitias ujian online untuk soal essay agar dapat dimungkinkan untuk menuliskan equation atau persamaan sehingga quiz dengan essay dapat dilakukan melalui online pula.

\section{DAFTAR PUSTAKA}

Asrul, Rusydi A., Rosnita. 2015. Evaluasi Pembelajaran. Medan: Citrapustaka Media.

Boeve, Anja J., Rob R. Meijer, Casper J. A., Yta B., Roel J. B., 2015. Introducing Computer Based Testing in High Stakes Exams in Higher Education: Results of a Field Experiment. Jourlnal Pone. 10(12) : 1-13. 
Maiziani, F. 2016. Efektivitas Computer Based Testing Sebagai Sarana Tes Hasil Belajar. Jurnal Kiprah. 4(1) : 15-32.

Mastuti, E. 2016. Pemanfaatan Teknologi Dalam Menyusun Evaluasi Hasil Belajar: Kelebihan dan Kelemahan "Tes Online" Untuk Mengukur Hasil Belajar Mahasiswa. Jurnal Penelitian Psikologi. 7(1): 10-19.

Mulyadi, M. 2011. Penelitian Kuantitatif dan Kualitatif Serta Pemikiran Dasar Menggabungkannya. Jurnal Studi Komunikasi dan Media. 15(1) : 127138.

Perkasa, D. A., Eka, S., Mona, F. 2015. Sistem Ujian Online Essay Dengan Penilaian Menggunakan Metode Latent Sematic Analysis (LSA). Jurnal Rekayasa dan Manajemen Sistem Informasi. 1(1) : 1-9.
Rahayu, D. S. 2016. Respon Mahasiswa Terhadap Pembelajaran Berbasis Proyek Pada Mata Kuliah Statistika. Jurnal Pendidikan dan Pembelajaran Matematika. 2(2): 1424.

Sujana, I W. C. 2019. Fungsi dan Tujuan Pendidikan Indonesia. Jurnal Pendidikan Dasar. 4(1) : 29-39.

Trisnawati, I. K. 2015. Validity in Computer Based Testing: A Literature Review of Comparability Issues and Examine Perspective. Englisia. 2(2) : 86-94.

Yuliyanto, H. 2016. Ujian Online Dalam E-Learning: Perbandingan Ujian Online (Computer Based) Terhadap Ujian Tradisional (Paper Based). Jurnal Vokasi Indonesia. 4(2) : 94104. 